\title{
The Development of National Steel Industry Strategies for the Future
}

\author{
$1^{\text {st }}$ Mohammad Hamsal ${ }^{1}, 2^{\text {nd }}$ Sri Bramantoro Abdinagoro ${ }^{2}$ \\ $\underline{\text { mhamsal@binus.edu }}{ }^{1},{\underline{\text { sabdinagoro@ } \text { binus.edu }^{2}}}^{2}$ \\ Management Department, BINUS Business School Doctor of Research in Management \\ Bina Nusantara University, Jakarta, Indonesia ${ }^{1,2}$
}

\begin{abstract}
Steel is a strategic commodity and a key industry in the Indonesian economy. This paper looks at prospects and the options facing by the industry in the future. New production capacity will have to be implemented but it will undoubtedly be difficult to realize this without external assistance and without diverting resources from other areas. Thus it will be necessary to plan for business innovation to achieve production capacity objectives, and such innovation must be developed in Indonesia, or imported, and adapted to suit local conditions. At the end, the industry should be able to effectively implement the developed scenarios and anticipate the early warning signals.
\end{abstract}

Keywords: steel industry, scenario planning, early warning signals, implementation plan

\section{Introduction}

In general, the global metal industry is undergoing a significant transformation through the disruption of economic, political, and technological factors (Naujok and Stamm, 2019). The steel industry is a strategic industry that has external influences, interconnected, and influencing the direction of its development going forward, and increasingly dynamic and complex over time (Maulana and Sunitiyoso, 2012) .

In 2017 Indonesia was ranked $13^{\text {th }}$ as importer steel country in the world with total 11,0 million metric ton. This means experience growth of import steel by $102 \%$ since 2009 . Though recorded import volume year-on-year down 9\%, however value up 19\%. Penetration import fixed $79.8 \%$ in 2015 and 2016 (World Steel Association, 2019). Whereas the top three importer countries are China, Japan, and South Korea (Nakoryakova et al., 2018).

Witnessed by BUMN Minister Rini Soemarno, on November 23, 2018, a Head of Agreement (HoA) was signed between PT. Krakatau Steel (Persero) Tbk. with PT. Wijaya Karya (Persero) Tbk., Waskita Karya (Persero) Tbk., PT. Adhi Karya (Persero) Tbk., PT. Hutama Karya (Persero) Tbk., PT. PP (Persero) Tbk., and PT. Nindya Karya (Persero). This signing marks the start of strengthening cooperation in the supply of steel products for the construction of government and private infrastructure projects (BUMN Track, 2018). This form of BUMN synergy is an initiative of PT. Krakatau Steel for the benefit of national development while strengthening the role of SOEs as agents of development and in turn are expected to become one of the competitive global steel players.

Leading consultant PwC predicts that in the 2012-2025 period, the average global steel demand growth will be $3.3 \%$ per year. Nearly half (49\%) were met by China, which is currently consolidating its steel industry. In 2010, China was the largest steel exporter in the world with a volume of 626.7 million tons, while Indonesia only ranked $37^{\text {th }}$ (Bloomberg Businessweek, 2011). The global steel producer giant is China which last year produced 831.7 
million tons, followed by Japan at 104.7 million tons and India at 101.4 million tons (Tempo, December 2018). Facing this increase, world-class steel companies from overseas need to make raw material efficiency and investment effectiveness, service delivery, and flexibility, improve product quality and innovation, commodity management, and utilization of information technology and digitalization (PwC, 2015).

Indeed the condition of the domestic steel industry is influenced by the global steel industry. It is undeniable that the Indonesian steel industry still has good prospects. Indonesia still has the opportunity to increase participation in the global steel industry. The total export of steel products in the form of semi-finished and finished products has reached 1 million tons per year (Bloomberg Businessweek, 2011). While national steel production and consumption during 2015-2017 can be seen in Table 1 below.

Table 1. Production vs. Consumption of National Steel (crude, million tons)

\begin{tabular}{|c|c|c|c|}
\hline Activities & $\mathbf{2 0 1 5}$ & $\mathbf{2 0 1 6}$ & $\mathbf{2 0 1 7}$ \\
\hline Production & 6.17 & 6.58 & 7.87 \\
\hline Consumption & 11.37 & 12.67 & 13,59 \\
\hline Deficit & 5,20 & 6.09 & 5.72 \\
\hline
\end{tabular}

Source: Tempo (2018); processed

In addition, the wave of cheap steel products has begun to enter Indonesia since 2005. Its factories have now reached ten and spread in Tangerang, Jakarta, Surabaya, and Sulawesi. They relocated themselves from China. Slowly this environmentally friendly and fragile steel product dominates the national reinforcing steel market, which is mostly used for the construction industry. Its market share has reached more than 70\% (Anam and Hardjono, 2018). In addition, steel importers from China also take advantage of the weakness of the rules by manipulating alloy steel tariffs to avoid imposing import duties (Adityowati and Anam, 2018). Until now, Indonesia continues to be flooded by imported steel products (Adityowati, 2019).

\section{Problem Identification}

Other problems are related to global steel business competition. For example, China has accused the practice of dumping steel companies from several countries including Indonesia. This is due to the impact of competition from state-owned steel companies with Chinese steel companies abroad (Widodo and Khusniah, 2018). However, although it is still small, Indonesia's participation and the development trend of the national steel industry is positive in line with the additional capacity of various local steel manufacturing companies, including state-owned enterprises. In addition to the relocation of Chinese steel plants to Indonesia, the new steel plant construction project is expected to reduce dependence on imported steel raw materials. Strong synergic, systematic and integrated activities are needed between national steel businesses, governments, research institutions, and other stakeholders to deal with various changes in the world economy that have an impact on the steel industry and global steel industry competition and other internal challenges and constraints. This is expected to be anticipated by domestic steel players with the support of a description of the national steel industry in the future. 


\section{Problem Formulation}

Facing the various phenomena of the global and national steel industry, plausible scenarios are needed to anticipate the development and growth of the national steel business in the future. National steel players can make it as inputs for development strategies and plans for implementing steel business in the country.

Related with above conditions, formulation problem in this research are:

1) How is the condition in the form of issues, obstacles, constraints, and opportunities faced by the national steel industry in developing national and global steel business?

2) How map development and enhance the competitiveness of the national steel industry in the face of global steel competition?

3) How concrete steps that need to be taken against the conditions global and national steel business?

4) What is the choice of the steel industry scenario and the plan for its implementation in the future?

\section{Research Objectives}

Based on the formulation of the problem above, this study aims to:

1) Evaluate latest developments and industry conditions and national steel business.

2) Describe the strategy of increasing the steel industry's competitive advantage .

3) Understand anticipatory action in the face of conditions in the item 1 above.

4) Design scenarios, early warning signals, and implementation plan for the national steel business development.

\section{Previous Research}

Scientific publications related to the national steel business are still very limited. While the reports of world-class consultants related to the study of global steel business are very many. Previous studies regarding the development of scenario planning in the steel business sector are given in Table 2 below.

TABLE 2. Previous Studies of Steel Industry Scenario Planning

\begin{tabular}{|c|l|l|l|l|}
\hline No. & \multicolumn{1}{|c|}{ Author } & \multicolumn{1}{|c|}{ Title } & Country & \multicolumn{1}{c|}{ Results } \\
\hline 1. & $\begin{array}{l}\text { Maulana \& } \\
\text { Sunitiyoso (2012) }\end{array}$ & $\begin{array}{l}\text { Scenario Planning } \\
\text { Development for PT. } \\
\text { Krakatau Steel }\end{array}$ & Indonesia & $\begin{array}{l}\text { Dimensions: } \\
\text { Government support } \\
\text { and global steel } \\
\text { commodity prices } \\
\text { Four scenario planning }\end{array}$ \\
\hline \multirow{2}{*}{$\begin{array}{l}\text { Chauhan (2017) } \\
\end{array}$} & $\begin{array}{l}\text { Indian Iron \& Steel } \\
\text { Industry: Present Scenario }\end{array}$ & India & $\begin{array}{l}\text { Global scenario } \\
\text { (optimistic and } \\
\text { pessimistic) }\end{array}$ \\
& & & $\begin{array}{l}\text { Identification of } \\
\text { problems in the iron } \\
\text { and steel industry of } \\
\text { India }\end{array}$ \\
\hline
\end{tabular}




\section{Literature Review}

\section{Definition of Scenario Planning}

Scenario planning is a sub-discipline of management, especially planning that is relatively young (Chermack, 2011). Scenario planning is not trying to predict the picture of the future rigidly. It has similarities with strategic planning in terms of a top-down approach. In scenario planning top management looks far ahead through various scenarios to anticipate events that might occur in order to develop a strategic response (Rothermermel, 2019).

Scenario planning aims to identify and explore various future developments realistically. The scenario that results from this thinking must be seen as an in-depth indicator of what can happen in the future, depending on the decision (Wade, 2012). According to Chermack (2011) the final output of scenario planning activities is (1) changes in way of thinking, (2) narratives or stories that are informative about future events, (3) better decision making about the future, and (4) improvement organizational learning and imagination and human resources. Scenarios are detailed descriptions of plausible future events and outcomes (Tighe, 2019).

\section{Role and Plan the Scenario}

The main purpose of scenarios is not to predict the future, but to enable better anticipations and decisions today and to give institutions to shape the future based on their aspiration (Tighe, 2019). Figure 1 shows the link between strategic intentions (vision, mission, and objectives), environmental factors (external and internal), SWOT, and aspects of strategic execution in order to realize the vision of the national steel industry in line with the aspiration of a steel SOE, namely: "becoming an integrated steel company with competitive edges to continuously grow towards leading global enterprise" (Annual Report, 2018: 32). Scenario planning is part of the latest study in the external and internal environment at the industry level.

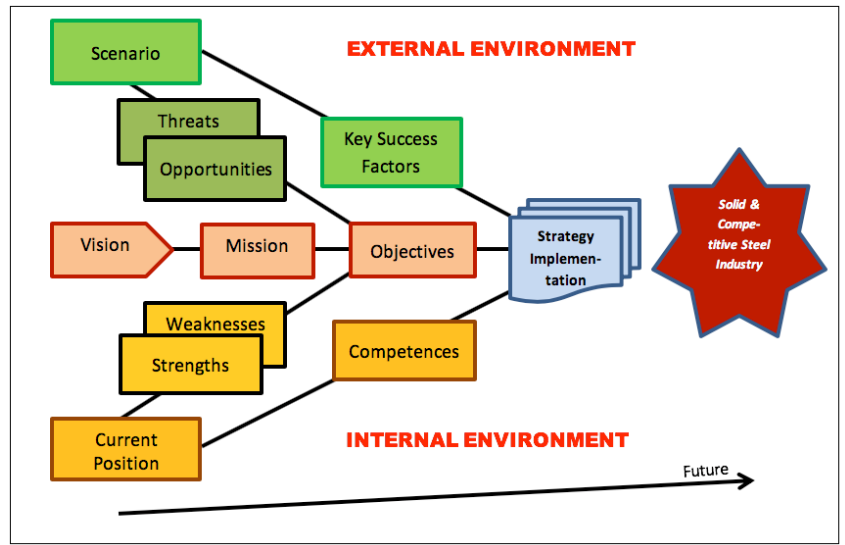

Fig. 1. Linkages to Strategic Intention, Environment, SWOT, and Implementation of Strategy

One of scenario planning objectives related to steel business development is to identify factors that can cause vulnerability in implementing the steel industry future action plan in the direction set. Thus, anticipatory action can be taken as early as possible through the detection of relevant early warning signals. 
According to Garvin and Levesque (2006), the steps in scenario planning generally consist of the following five stages (see Figure 2).

1) Orientation, by identifying key issues (key focal issues);

2) Exploration, by defining driving forces;

3) Scenario development, namely creating various scenarios and narratives (scenarios and narratives);

4) Implications and options, by describing the impact and choice of action plans as anticipatory actions; and

5) Integration, by identifying early warning signals.

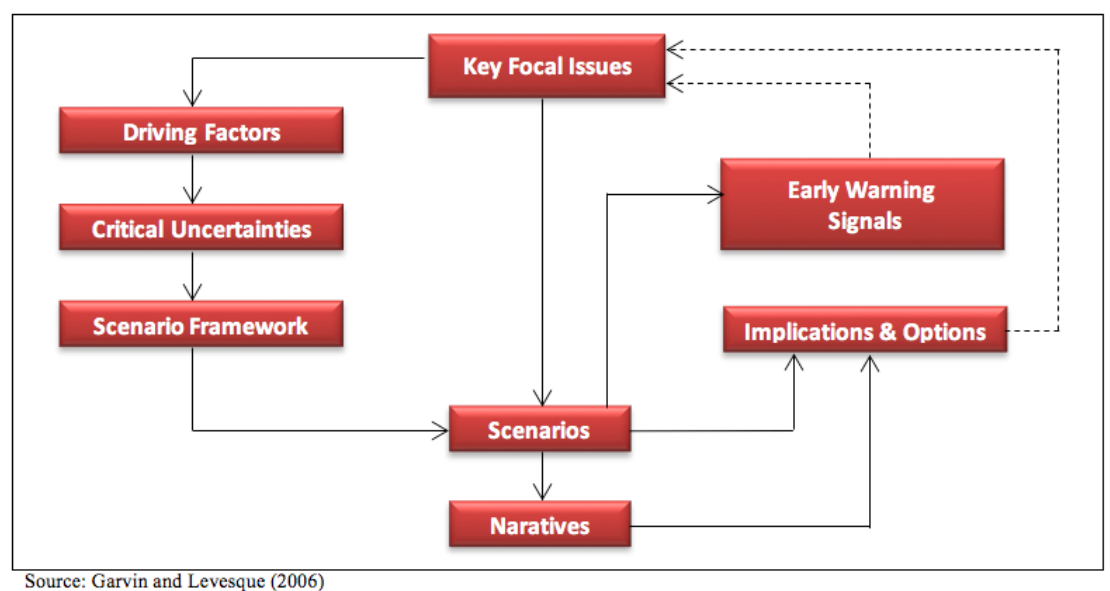

Fig. 2. Scenario Planning Steps

While according to Kahane (2012) there are five steps of scenario planning, namely:

- Stage 1: Coinitiating (forming teams representing various organizational functions)

- $\quad$ Stage 2: Cosensing (watching what is happening)

- $\quad$ Stage 3: Cosensing (constructing the story of what will happen)

- $\quad$ Stage 4: Copresencing (finding what can and should be done )

- $\quad$ Stage 5: Cocreating (acting to transform the organization)

\section{Research Method}

The research method is qualitative and descriptive with analysis unit are regulator, expert, resource person, and staff of steel SOE engaged in business steel long-products. Observation coverage is nature one shoot / cross sectional. The research design is showed in Table 3 .

Table 3. Research Design

\begin{tabular}{|c|c|c|c|c|}
\hline \multirow{2}{*}{$\begin{array}{c}\text { Aim } \\
\text { Research }\end{array}$} & \multicolumn{3}{|c|}{ Design } \\
\cline { 2 - 5 } & $\begin{array}{c}\text { Type } \\
\text { Research }\end{array}$ & $\begin{array}{c}\text { The method D } \\
\text { igunakan }\end{array}$ & Unit of Analysis & Horizon Time \\
\hline T-1 & Descriptive & $\begin{array}{l}\text { Open-ended } \\
\text { interview }\end{array}$ & $\begin{array}{l}\text { Organization } \rightarrow \text { Steel SOE. } \\
\text { Personal } \rightarrow \text { Staff Business }\end{array}$ & $\begin{array}{l}\text { One shoot - cross } \\
\text { sectional }\end{array}$ \\
\hline
\end{tabular}




\begin{tabular}{|c|l|l|l|l|}
\hline & & & Development \& Marketing. & \\
\hline T-2 & Descriptive & $\begin{array}{l}\text { Open-ended } \\
\text { interview }\end{array}$ & $\begin{array}{l}\text { Organization } \rightarrow \text { Department of } \\
\text { Metallurgical \& Material } \\
\text { Engineering, Faculty of } \\
\text { Engineering, University of } \\
\text { Indonesia. }\end{array}$ & $\begin{array}{l}\text { One shoot - cross } \\
\text { sectional }\end{array}$ \\
\hline T-3 & Descriptive & $\begin{array}{l}\text { Open-ended } \\
\text { interview }\end{array}$ & $\begin{array}{l}\text { Organization } \rightarrow \text { Leader of Ministry } \\
\text { Industry. }\end{array}$ & $\begin{array}{l}\text { One shoot - cross } \\
\text { sectional }\end{array}$ \\
\hline
\end{tabular}

Method Analysis

The method analysis in this research can be seen on Table 4 below.

Table 4. Method Analysis

\begin{tabular}{|c|l|}
\hline Aim Research & \multicolumn{1}{c|}{ Method Analysis } \\
\hline T-1 & Descriptive - Protocol Interview \\
\hline T-2 & Descriptive - Protocol Interview \\
\hline T-3 & Descriptive - Protocol Interview \\
\hline T-4 & Study and overview from the results of T-1, T-2 \& T-3 \\
\hline
\end{tabular}

Description :

T-1: Dig issues, obstacles, and constraints faced and opportunities that arise to product steel

T-2: Knowing the various actions which have been taken to make use of and develop steel business

T-3: Map development of national steel products

$\mathrm{T}-4$ : Conduct scenario planning and implementation aspect

\section{DISCUSSION: SCENARIO PLANNING DEVELOPMENT}

Based on scenario planning steps developed by Kahane (2012) and Garvin and Levesque (2006), the development of national steel industry scenario planning can be described as follows:

\section{- $\quad$ Stage 1: Orientation}

A key issue identified by authorities and experts is "How to develop strong and competitive national steel industry."

- $\quad$ Stage 2: Exploration

Driving factors: Table 5 shows various driving factors were identified based on the results of a literature review, expert interviews, and FGD with a steel SOE staff.

TABLE 5. Driving Factors and Key Strengths

\begin{tabular}{|c|c|c|c|}
\hline Analysis & $\begin{array}{c}\text { Strategic Input } \\
\text { Aspects }\end{array}$ & Driving factors & Critical Category \\
\hline External & Economic Trends & $\begin{array}{l}\text { - Infrastructure development } \\
\text { - Business expansion/market } \\
\text { - Business profitability } \\
\text { - Availability of vendors } \\
\text { - Steel commodity prices } \\
\text { - Level of competition }\end{array}$ & $\begin{array}{l}\text { Domestic demand } \\
\text { rate }\end{array}$ \\
\hline
\end{tabular}




\begin{tabular}{|c|c|c|c|}
\hline & & - Customer satisfaction & \\
\hline & Socio-cultural & - Customer demands & \\
\hline & $\begin{array}{l}\text { Technology } \\
\text { changes }\end{array}$ & $\begin{array}{l}\text { - Ability to transfer technology } \\
\text { - Availability of software }\end{array}$ & \\
\hline & $\begin{array}{l}\text { Environmental } \\
\text { Issues }\end{array}$ & Pollution and factory relocation & \\
\hline & $\begin{array}{l}\text { Regulatory / } \\
\text { Regulatory Issues }\end{array}$ & Government support \& policy & \\
\hline \multirow[t]{5}{*}{ Internal } & Strategic Resources & $\begin{array}{l}\text { - Main raw material } \\
\text { - Production system } \\
\text { - Supply chain } \\
\text { - Readiness of human capital } \\
\text { - Expired knowledge } \\
\text { - Culture of knowledge sharing }\end{array}$ & \multirow[t]{5}{*}{$\begin{array}{l}\text { Conditions of } \\
\text { production capacity }\end{array}$} \\
\hline & Capability level & Enhanced innovation capabilities & \\
\hline & Current Strategy & Repair work continues continuously & \\
\hline & $\begin{array}{l}\text { Level of } \\
\text { Understanding \& } \\
\text { Awareness }\end{array}$ & Job and work orientation & \\
\hline & Strategic Harmony & $\begin{array}{l}\text { Cooperation and business } \\
\text { partnerships }\end{array}$ & \\
\hline
\end{tabular}

Critical Uncertainty: Furthermore, a review of the various driving factors above is carried out and dividing it into several groups and ranking according to the level of importance and uncertainty. Table 6 shows the top two factors that contain critical uncertainty.

Table 6. Ranking of Drivers with Critical Uncertainty

No. Critical Uncertainty

1. Domestic Demand Rate

2. Conditions of Production Capacity

\section{- $\quad$ Stage 3: Scenario Development}

Step 1: Scenario making is developed based on these two critical uncertainty factors. Then, develop a scenario matrix as shown in Figure 3.

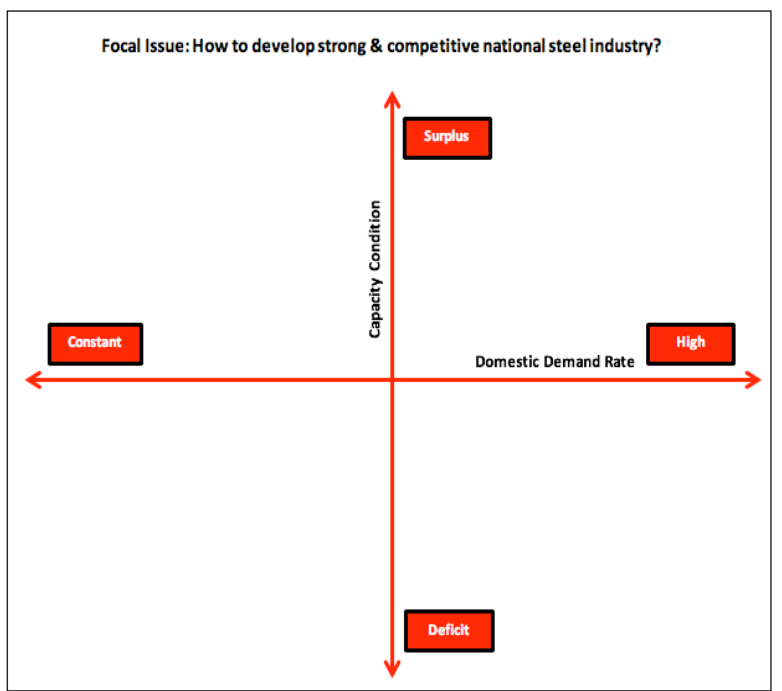


Fig. 3. Axis Scenario for the Development of the National Steel Industry

Step 2: Next, give a title and write a narrative for the four scenarios developed. Figure 4 shows briefly the description of each scenario for the development of a strong and competitive national steel industry. The themes or titles of each scenario are taken from box-office films by Walt Disney.

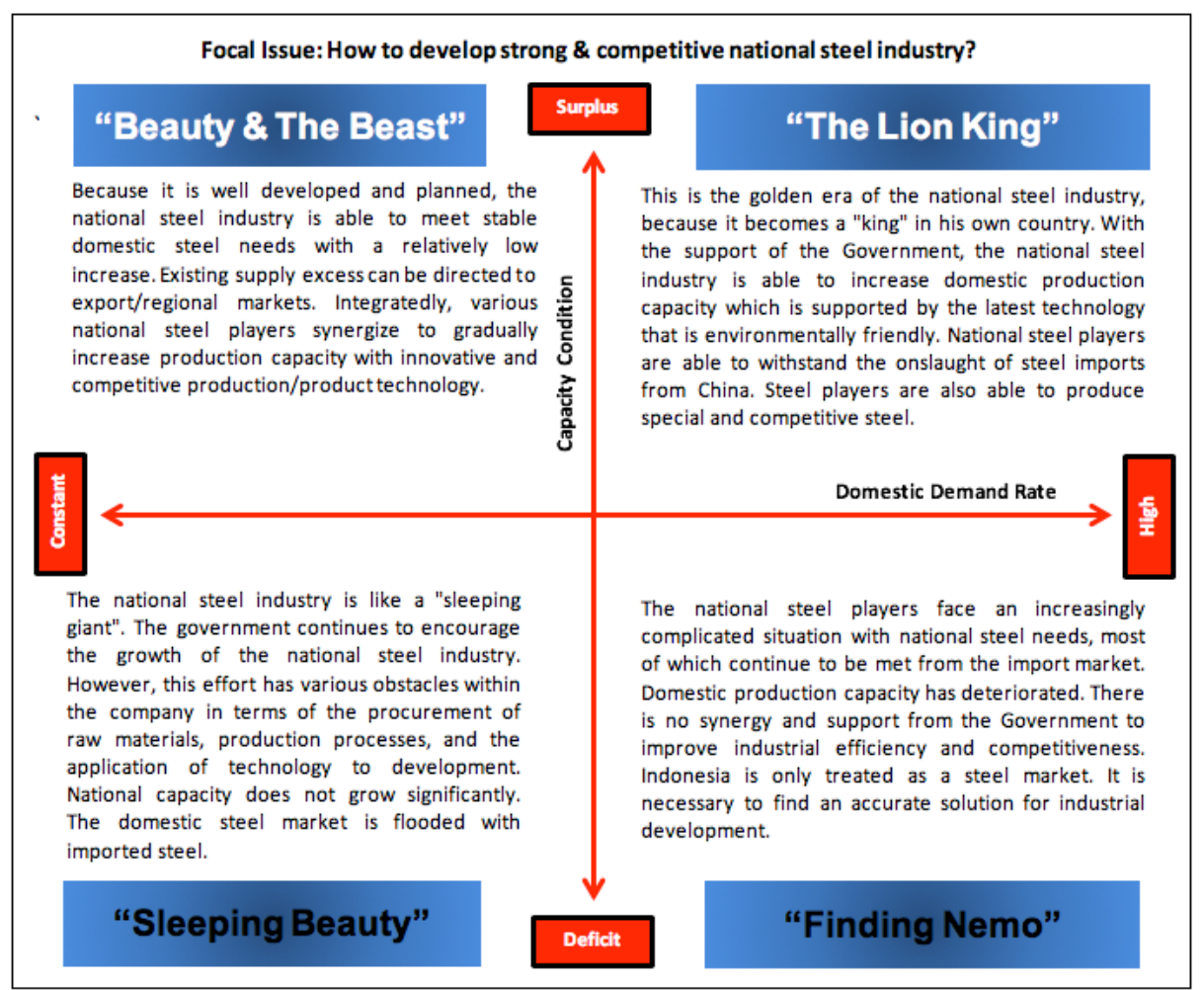

Fig. 4. Brief Narrative of the Scenarios of the National Steel Industry

\section{- $\quad$ Stage 4: Implications and Options}

Based on the story line that was developed in each scenario in Figure 4, then outlined the various implications that may shortly become challenges from each scenario for the development of the national steel industry and action plans in order to overcome the factors that are vulnerable to changes in the steel industry towards a competitive industry. Figure 5 shows the impact and response action plan for each scenario. 


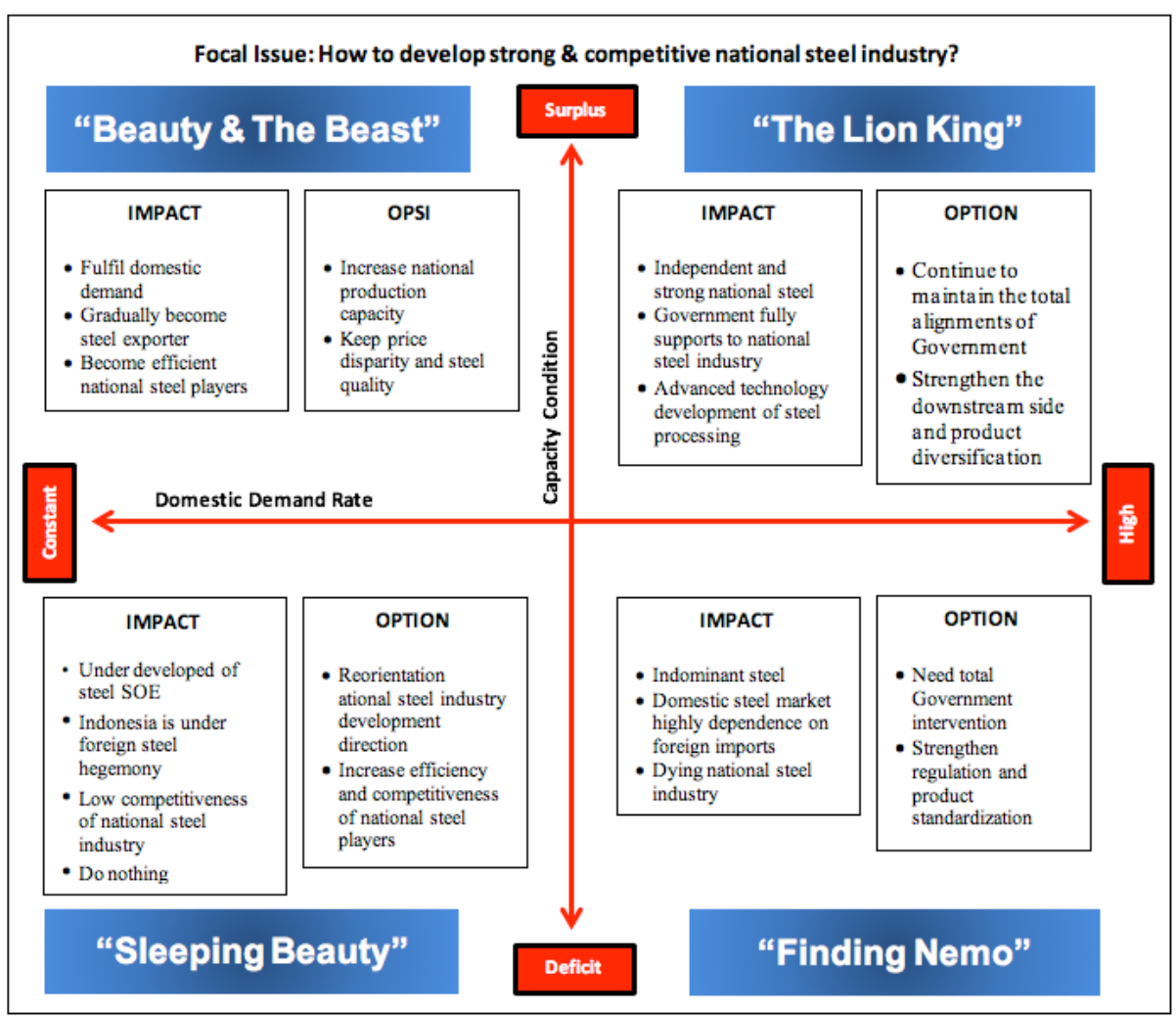

Fig. 5. Implications and Prevention Options

\section{- $\quad$ Stage 5: Integration}

Finally, an early warning signal is identified that needs to be watched out by related parties in the framework of developing the national steel industry. This early warning signal is determined based on a combination of the various implications and options outlined in Figure 5. Furthermore, the five priority warning signals for the national steel industry are shown in Table 7.

Table 7. Early Warning Signals

\begin{tabular}{|c|c|}
\hline 1. & There is no total alignment from the Regulator/Government \\
\hline 2. & Renewal of national steel processes and technology is still in place \\
\hline & $\begin{array}{l}\text { The need for protection through standardization that is maintained at } \\
\text { regular intervals }\end{array}$ \\
\hline & $\begin{array}{l}\text { Strengthen strategic alliances/partnerships but ensure effective transfer of } \\
\text { technology and knowledge }\end{array}$ \\
\hline & $\begin{array}{l}\text { It is necessary to encourage the development of special steel products produced } \\
\text { based on environmentally friendly }\end{array}$ \\
\hline
\end{tabular}




\section{Conclusion}

Every country needs a giant industry as a "locomotive" that supports and drives the economy. The steel industry can consist of large private companies and especially state-owned companies. It cannot be denied that the steel industry provides many benefits and contributions to the prosperity of the country and nation.

Internally, in order to achieve sustainable competitive advantage, the steel industry needs to immediately develop core competences in the form of adaptive learning organizations and renewal of existing knowledge into human capital that supports the company's competitive advantage in facing regional and global competition.

In line with this initiative, based on interactions with related parties, four basic scenarios have been developed for the development of the national steel industry through systematic steps. This scenario also refers to aspects of the dependence and complexity of business and markets faced by the national steel industry in the future. The scenario of "Beauty and the Beast" may require increased domestic production capacity significantly through expansion and steel processing technology selection process more efficient. The scenario of "Lion King" is characterized by a national steel industry that is fully supported by the Government and strengthens the downstreaming and diversification of steel products, including special steel. This scenario is ideal for the national steel industry in order to accelerate into a world-class steel industry. In this scenario the synergy between universities, companies, and the Government remain aligned and maintained. While in scenario of "Sleeping Beauty", Indonesia is in the grip of steel imports and national steel players are stuck on status quo situations that lead to their lack of innovativeness and creativity. Finally, the scenario of "Finding Nemo" makes national steel industry increasingly dependent on imports of steel by the lack of synergies and the strengthening of the industry. This is done because the players of the national steel prioritize business survival. Every national steel player thinks individually and is transactional in dealing with internal problems and challenges for future business growth.

All developed scenarios require anticipatory steps on the five main early warning signals that will make the implementation of the scenario effective. In other words, the five early warning signals can be an obstacle to the implementation of the scenarios that have been developed. These early warning signals provide a sign that the national steel industry must be fully supported by its development and always learn faster than competitors in other countries, avoid being in a comfort zone, and respecting their rights and obligations as the spearhead of human capital and knowledge development, as a source of competitive advantage towards the world-class steel industry. There is no need to wait too long that there will indeed be many players in the Indonesian steel industry in the future will take part and become a leader in the global market arena.

\section{Acknowledgment}

The authors would like to thank BINUS University which provides Research Grants in 2019 so that the research can be conducted. 


\section{References}

[1] "Industri Baja Indonesia Semakin Kuat". Bloomberg Businessweek. 2-15 June. 4 (2011).

[2] "Prospek Industri Baja di Indonesia". Bloomberg Businessweek. 6-12 October. 6 (2011).

[3] "Krakatau Steel Gandeng BUMN Karya". BUMN Track. 11(131). 66-67. (2018)

[4] Adityowati, P. (2019). “Lenggang Kangkung Baja Paduan”. Tempo. 17 March. 90-91.

[5] Adityowati, P. and K. Anam (2018). "Bermain Kode Tarif Murah". Tempo. 23 December. 86-87.

[6] Anam, K. and J. Hardjono (2018). "Dalam Cengkeraman Baja Induksi”. Tempo. 23 December. 80-82.

[7] Chauhan, D. K. (2017). "Indian Iron and Steel Industry: Present Scenarios and Problems". Steelworld. December 30-31.

[8] Chermack, T. J. (2011). Scenario Planning in Organizations. San Francisco: BerrettKoehler Publishers.

[9] Garvin, D. A. and Levesque, L. C. (2006). “A Note on Scenario Planning”. Harvard Business School Lecture Note.

[10] Kahane, A. (2012). Transformative Scenario Planning. San Francisco: Berrett-Koehler Publishers.

[11] Maulana, M. T. and Y. Sunitiyoso (2012). "Scenario Planning Development for PT. Krakatau Steel". The Indonesian Journal of Business Administration. 1(3). 146-151.

[12] Naujok, N. and H. Stamm (2019). "Agility in Metals: Digital Transformation in the Steel and Aluminium Industry". Strategy\&. PricewaterhouseCoopers.

[13] Nakoryakova, L.; D. Kasatkin and Y. Afanasyeva (2018). Overview of the Steel and Iron Ore Market. Moskow: Deloitte CIS Research Centre.

[14] PT. Krakatau Steel Tbk. (Persero) (2019). Annual Report 2018.

[15] PwC (2015). Steel in 2025: Quo Vadis? PricewaterhouseCoopers. July.

[16] Rothaermel, F. T. (2019). Strategic Management: Concepts \& Cases. $4^{\text {th }}$ Edition, New York: McGraw-Hill.

[17] Sowar, N. and K. Gromley (2011). "A Sharper View: Analytics in the Global Steel Industry". Deloitte Global Services Ltd.

[18] Tighe, S. (2019). Rethinking Strategy. Melbourne: John Wiley \& Sons Australia.

[19] Wade, W. (2012). Scenario Planning: A Field Guide to the Future. Hoboken, N. J.: John Wiley \& Sons.

[20] Widodo, M. S. and U. Khusniah (2018). "Ketika Baja Lokal Cina Menderita”. Gatra. 15 August. 44-47.

[21] World Steel Association (2019). World Steel in Figures 2018. World Steel Association. [22] Zemlyanskaya, L. and D. Kasatkin (2017). Overview of Steel and Iron Market. Moskow: Deloitte. 